\title{
Trinexapac-ethyl and topdressing nitrogen levels on the productivity and physiological quality of graniferous white oat seeds ${ }^{1}$
}

\author{
José Henrique Bizzarri Bazzo ${ }^{2 *}$, Carlos Roberto Riede ${ }^{3}$, \\ Klever Marcio Antunes Arruda ${ }^{3}$, André Prechlak Barbosa ${ }^{2}$, \\ Inês Cristina de Batista Fonseca², Claudemir Zucareli ${ }^{2}$
}

\begin{abstract}
The aim of this study was to evaluate the physiological quality of white oat seeds cultivated under different topdressing $\mathrm{N}$ levels combined with the plant growth retardant trinexapac-ethyl in two growing environments. The experiments were carried out in Londrina and Mauá da Serra Municipalities (PR, Brazil) with the cultivar 'IPR Afrodite'. The experimental design was in randomized blocks, in a 4x2 factorial arrangement, with four replications. Treatments consisted of four $\mathrm{N}$ levels $\left(0,30,60\right.$, and $\left.90 \mathrm{~kg} \cdot \mathrm{ha}^{-1}\right)$ combined or not with the plant growth retardant. Seed yield, 1000-seed weight, germination, first germination count, seedling length, seedling dry matter, accelerated aging, electrical conductivity, emergence speed index, and seedling emergence in sand were evaluated. Data were submitted to the analysis of variance and then to the $\mathrm{F}$ test and regression analysis up to the second degree $(\mathrm{p} \leq 0.05)$. The application of the plant growth retardant and $\mathrm{N}$ topdressing led to an increase in seed productivity in Mauá da Serra. $\mathrm{N}$ fertilization reduced seed quality, but this effect can be minimized, not observed or overlapped by the positive effect of the plant growth retardant. Such an effect depends on environmental characteristics and it was not observed in Londrina.
\end{abstract}

Index terms: plant growth retardant, lodging, nitrogen fertilization, vigor, germination.

\section{Trinexapac-ethyl e doses de nitrogênio em cobertura na produtividade e qualidade fisiológica de sementes de aveia branca granífera}

\begin{abstract}
RESUMO - Objetivou-se avaliar a qualidade fisiológica de sementes de aveia branca cultivada sob diferentes doses de nitrogênio em cobertura, associadas ao redutor de crescimento trinexapac-ethyl em dois ambientes de cultivo. Os experimentos, em Londrina-PR e Mauá da Serra-PR, foram conduzidos utilizando-se a cultivar IPR Afrodite, em delineamento experimental de blocos casualizados em esquema fatorial 4 x 2, com quatro repetições. Os tratamentos constaram de quatro doses de nitrogênio $(0,30,60$ e 90 kg.ha-1) associadas ou não ao redutor de crescimento. Foram avaliados: produtividade de sementes, massa de mil sementes, geminação, primeira contagem de germinação, comprimento e massa seca de plântulas, envelhecimento acelerado, condutividade elétrica, índice de velocidade de emergência e emergência de plântulas em areia. Os dados foram submetidos a análise de variância e, posteriormente, ao teste $\mathrm{F}$ e a regressão até $2^{\circ}$ grau $(\mathrm{p} \leq 0.05)$. A aplicação do redutor de crescimento e da adubação nitrogenada de cobertura aumenta a produtividade de sementes em Mauá da Serra. A adubação nitrogenada reduz a qualidade das sementes, contudo este efeito pode ser minimizado, não observado ou sobreposto pelo efeito positivo do redutor de crescimento. Este efeito depende das características do ambiente e não foi observado em Londrina.
\end{abstract}

Termos para indexação: redutor de crescimento, acamamento, adubação nitrogenada, vigor, germinação.

\section{Introduction}

High productions can be reached with high-quality seeds - inputs responsible for the emergence and uniform establishment of a suitable stand, which consist of basic requirements for a cultivation with a high grain yield potential (Oliveira et al., 2014).

\footnotetext{
${ }^{1}$ Submitted on 07/25/2017. Accepted for publication on 05/30/2018. ${ }^{2}$ Departamento de Agronomia, Universidade Estadual de Londrina, Caixa Postal 6001, 86057-970 - Londrina, Paraná, Brasil.
} ${ }^{3}$ Instituto Agronômico do Paraná, 86047-902 - Londrina, Paraná, Brasil.
*Corresponding author < agro.bazzo@gmail.com> 
Sá (1994) stated that nutrient availability to plants might interfere with seed quality, since such a factor is related to chemical composition, embryo formation, and reserve structures and, then, physiological performance. The same author mentioned that well-nourished plants have better conditions of producing a larger number of high-quality seeds.

According to Kolchinski and Schuch (2004), seed quality can be affected by $\mathrm{N}$ supply to plants, since $\mathrm{N}$ is component of biomolecules acting on key metabolic pathways and vital processes in plants. The same authors reported that the amount of absorbed $\mathrm{N}$ during the plant life cycle has a great influence on seed protein content. In this sense, Carvalho and Nakagawa (2012) observed a positive correlation between protein content and physiological quality of wheat seeds.

High $\mathrm{N}$ levels positively influence the productivity of white oat grains/seeds (Kolchinski and Schuch, 2004). However, this procedure can increase the vegetative growth, thus resulting in taller plants, leading to their lodging, which negatively interferes with seed production and quality (Zagonel and Fernandes, 2007).

Plant growth retardants affect plant hormone balance by inhibiting gibberellin synthesis (Rademacher, 2015) in order to decrease height, thus preventing a possible plant lodging. In this context, their use can be an important strategy to solve this problem (Pagliosa et al., 2013) and favor the obtainment of seeds with high physiological quality (Kappes et al., 2012), mainly in combination with high $\mathrm{N}$ levels.

In addition to their use aimed at reducing height and lodging in crops (Espindula et al., 2010), plant growth retardants have been applied to change plant architecture, especially of the flag leaf, which becomes more upright (Penckowski and Fernandes, 2010), thus increasing the use of environmental resources, especially solar radiation (Zagonel and Fernandes, 2007). This fact can change photoassimilate partitioning and improve grain filling, thus improving seed physiological quality (Sawan et al., 2009).

The growing environment and its interaction with management and genotype can also influence seed formation and, then, determine its physiological potential according to better or worse climate conditions during plant maturation (Gomes et al., 2012). Motta et al. (2002) stated that seed quality is influenced by growing locations and periods, since edaphoclimatic factors change in function of season and latitude. The understanding of the relationship between environmental conditions of the growing location and the productive performance of cultivars is essential for producing high-quality seeds with a satisfactory productivity.

Studies correlating the effects of the application of plant growth retardants, $\mathrm{N}$ topdressing, and growing environment on the physiological quality of white oat seeds and other cereals have been scarce, thus demonstrating the need for studies on such an issue in order to set suitable recommendations of these management techniques for the production of seeds with high physiological quality.

In this sense, the present study aimed at evaluating the physiological quality of graniferous white oat seeds cultivated under different topdressing $\mathrm{N}$ levels combined with the plant growth retardant trinexapac-ethyl in two growing environments.

\section{Material and Methods}

Experiments were carried out with the graniferous white oat 'IPR Afrodite' cultivar (mid-term life cycle, moderate resistance to lodging, and medium height) in two growing environments in Paraná State (PR), Brazil - Londrina and Mauá da Serra Municipalities, which are contrasting as to edaphoclimatic characteristics. In Londrina, the trial was carried out in the Experimental Farm of the Instituto Agronômico do Paraná (IAPAR), in a eutrophic Red Latosol located at $23^{\circ} 23^{\prime} \mathrm{S}, 51^{\circ} 11^{\prime} \mathrm{W}$, and $610 \mathrm{~m}$ altitude. This region has a Cfa climate, described as humid subtropical with hot summers, according to the Köppen climate classification. In Mauá da Serra, the trial was carried out in the 'Estância 3M' Farm, in a dystrophic Red Latosol (Oxisol) located at $23^{\circ} 58^{\prime} \mathrm{S}, 51^{\circ} 19^{\prime} \mathrm{W}$, and $847 \mathrm{~m}$ altitude. This region has a $\mathrm{Cfb}$ climate, described as mesothermal temperate with cool summers, according to the Köppen climate classification. Data of rainfall and temperatures were obtained from records of weather stations of IAPAR (Figure 1).

Soil chemical properties were determined at $0-20 \mathrm{~cm}$ depth before the beginning of the experiment in Londrina and consisted of $\mathrm{pH}\left(\mathrm{CaCl}_{2}\right) 5.20 ; 5.55 \mathrm{cmol}_{\mathrm{c}} \cdot \mathrm{dm}^{-3} \mathrm{H}+\mathrm{Al}^{3+} ; 4.90$ $\mathrm{cmol}_{\mathrm{c}} \cdot \mathrm{dm}^{-3} \mathrm{Ca}^{2+} ; 2.73 \mathrm{cmol}_{\mathrm{c}} \cdot \mathrm{dm}^{-3} \mathrm{Mg}^{2+} ; 0.80 \mathrm{cmol}_{\mathrm{c}} \cdot \mathrm{dm}^{-3} \mathrm{~K}^{+}$; $25.0 \mathrm{mg} . \mathrm{dm}^{-3} \mathrm{P}$; and $16.55 \mathrm{~g} . \mathrm{dm}^{-3}$ organic matter. For Mauá da Serra, values were: $\mathrm{pH}\left(\mathrm{CaCl}_{2}\right) 4.85 ; 7.48 \mathrm{cmol}_{\mathrm{c}} \cdot \mathrm{dm}^{-3} \mathrm{H}+$ $\mathrm{Al}^{3+} ; 6.38 \mathrm{cmol}_{\mathrm{c}} \cdot \mathrm{dm}^{-3} \mathrm{Ca}^{2+} ; 1.53 \mathrm{cmol}_{\mathrm{c}} \cdot \mathrm{dm}^{-3} \mathrm{Mg}^{2+} ; 0.35 \mathrm{cmol}_{\mathrm{c}}$. $\mathrm{dm}^{-3} \mathrm{~K}^{+} ; 17.5 \mathrm{mg}$. dm ${ }^{-3} \mathrm{P}$; and $28.82 \mathrm{~g}$. $\mathrm{dm}^{-3}$ organic matter.

At each location, the experimental design was in randomized blocks, in a $4 \times 2$ factorial arrangement, with four replicates. Treatments consisted of four topdressing $\mathrm{N}$ levels $\left(0,30,60\right.$, and $\left.90 \mathrm{~kg} \cdot \mathrm{ha}^{-1}\right)$ combined or not with the plant growth retardant.

The white oat cultivar was mechanically sown under a direct sowing system in areas previously used for soybean cultivation in Londrina and Mauá da Serra on May 08, 2014 and May 12, 2014, respectively, at 300 viable seeds. $\mathrm{m}^{-2}$. Plots consisted of six lines, each one with $5 \mathrm{~m}$ length, $0.17 \mathrm{~m}$ spacing between lines, and $4.25 \mathrm{~m}^{2}$ useful area. 

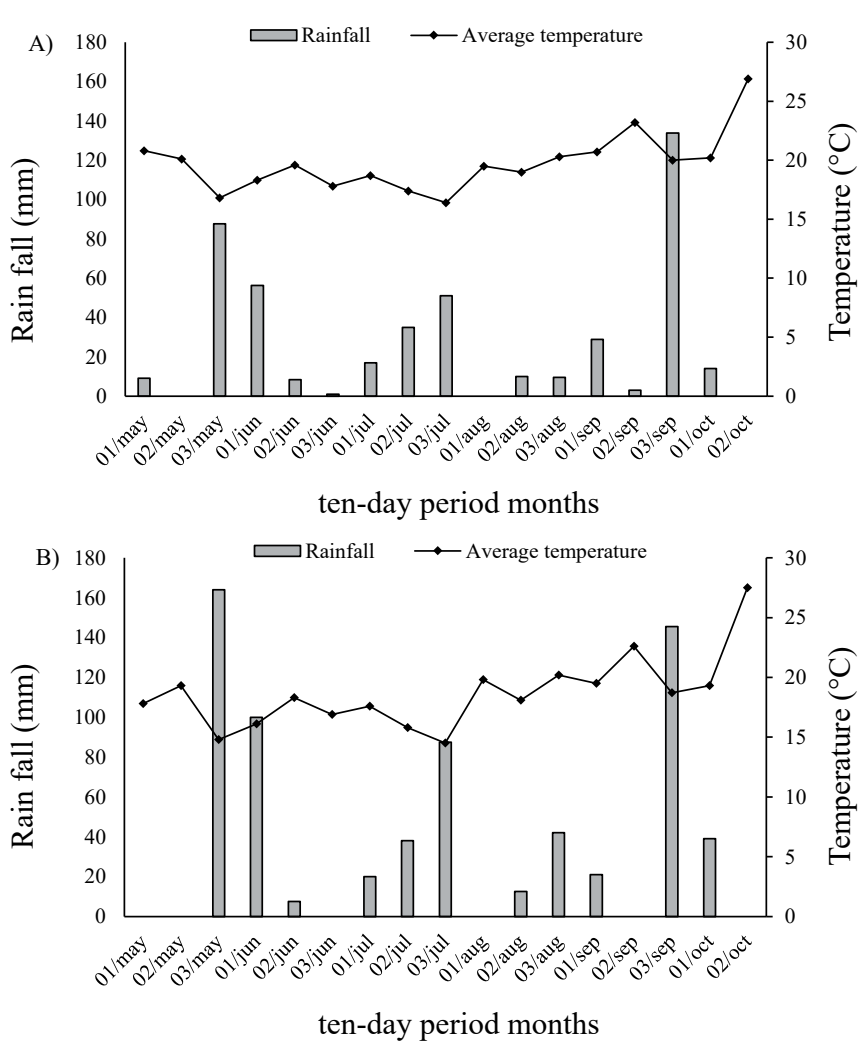

Figure 1. Rainfall (total accumulated during the ten-day period) and average temperature in the experimental period in Londrina-PR (a) and Mauá da Serra-PR (b), 2014.

Based on soil chemical properties of experimental areas, the basic mineral fertilization - constant for all treatments - in the sowing groove was $30 \mathrm{~kg}$. ha ${ }^{-1} \mathrm{~N}, 90 \mathrm{~kg} . \mathrm{ha}^{-1} \mathrm{P}_{2} \mathrm{O}_{5}$, and 30 kg.ha-1 $\mathrm{K}_{2} \mathrm{O}$ in Londrina, and $20 \mathrm{~kg}$. ha- ${ }^{-1} \mathrm{~N}, 60 \mathrm{~kg}$. ha ${ }^{-1} \mathrm{P}_{2} \mathrm{O}_{5}$, and $20 \mathrm{~kg}$. ha- $\mathrm{K}_{2} \mathrm{O}$ in Mauá da Serra, using the formulation 10-30-10 for both growing environments. Broadcast $\mathrm{N}$ topdressing was performed during tillering as urea $(45 \% \mathrm{~N})$.

Trinexapac-ethyl was applied at the stage of thatch elongation between the first and the second visible nodes at $125 \mathrm{~g}$ a.i. ha ${ }^{-1}$, corresponding to $400 \mathrm{~mL}$. ha ${ }^{-1}$ Moddus ${ }^{\circledR}$. The application was performed through a pressurized compressed $\mathrm{CO}_{2}$ knapsack mistblower at $30 \mathrm{lb}$. pol$^{-2}$ constant pressure, with two fan-type nozzles (XR 110-020) at $200 \mathrm{~L} . ~ h a^{-1}$ proportional syrup volume.

Management and cultural practices were performed according to requirements and recommendations for oat crop (CBPA, 2014). The harvest was performed after seed maturity, represented by caryopsis hardening, plants with a dry aspect, and grains with humidity below $20 \%$. Seed physiological quality was determined as follows.

Seed productivity: determined by the harvest of seeds from plants located in the useful area of plots. After mechanical threshing, seeds were weighed and data converted into kg.ha- ${ }^{-1}$ at $13 \%$ humidity.

1000-seed weight: obtained by counting and weighing of eight replicates of 100 white oat seeds per plot. The average of such values was multiplied by 10 (Brasil, 2009).

Germination: eight replications of 50 seeds were placed on Germitest ${ }^{\circledR}$ papers moistened with distilled water at 2.5fold volume relative to the weight of the dry paper. Seeds were maintained in a germination chamber at $20{ }^{\circ} \mathrm{C}$. Two counts were performed, i.e. at five (first count) and ten (second count) days after the beginning of the test, including the percentage of normal seedlings (Brasil, 2009).

Seedling length: four replications of 20 seeds were sown on the upper third of Germitest ${ }^{\circledR}$ papers moistened with distilled water at 2.5 -fold volume relative to the weight of the dry paper. Seeds were maintained in a germination chamber at $20^{\circ} \mathrm{C}$ for five days, when the length of normal seedlings was measured through a millimeter ruler. Results were expressed in $\mathrm{cm}$.

Seedling dry matter: after measurement of their length, normal seedlings were placed into paper bags and maintained in a forced aeration oven at $80{ }^{\circ} \mathrm{C}$ until obtaining a constant weight (Nakagawa, 1999). Then, dry matter was quantified and expressed in mg per seedling.

Accelerated aging: eight replications of 240 seeds per treatment were placed into gerboxes containing $40 \mathrm{~mL}$ water and an aluminum screen, on which seeds were uniformly distributed. Gerboxes were maintained in an accelerated aging chamber at $42{ }^{\circ} \mathrm{C}$ for $48 \mathrm{~h}$ (Marcos-Filho, 1999). Then, the germination test was carried out at $20^{\circ} \mathrm{C}$. The number of normal seedlings was counted five days after the beginning of the test (Brasil, 2009).

Electrical conductivity: four replications of 50 seeds were weighed, subsequently placed into plastic cups containing $75 \mathrm{~mL}$ deionized water and maintained at $25^{\circ} \mathrm{C}$. After $24 \mathrm{~h}$ imbibition, electrical conductivity was measured in the solution and expressed in $\mu \mathrm{S} . \mathrm{cm}^{-1} \cdot \mathrm{g}^{-1}$ (Vieira and Krzyzanowski, 1999).

Seedling emergence in sand: performed in a greenhouse, with four replications of 50 seeds per treatment sowed at $3 \mathrm{~cm}$ depth. Sand was previously washed and subsequently placed into plastic trays. The moisture was maintained by irrigation as needed. The number of emerged normal seedlings was counted on the $15^{\text {th }}$ day.

Emergence speed index of seedlings: performed simultaneously to the seedling emergence test in sand through daily counts of the number of emerged normal seedlings until emergence stabilization, according to the formula proposed by Maguire (1962).

Data were submitted to the analysis of variance and, then, means were compared by the Tukey test and submitted 
to the regression analysis (up to the second degree) for each growing environment separately ( $\mathrm{p} \leq 0.05)$.

\section{Results and Discussion}

For seeds produced in Londrina, a significant interaction was observed between the factors plant growth retardant and topdressing $\mathrm{N}$ levels for seedling length and dry matter. Germination, accelerated aging, and electrical conductivity showed an isolated effect of the plant growth retardant. $\mathrm{N}$ levels had a significant effect only on accelerated aging.

For seeds produced in Mauá da Serra, a significant interaction was observed between the factors plant growth retardant and topdressing $\mathrm{N}$ levels for seedling length and dry matter, accelerated aging, and seedling emergence. The plant growth retardant had an isolated effect on seed productivity, germination, first germination count, and electrical conductivity. On the other hand, $\mathrm{N}$ levels had an isolated effect on seed productivity, germination and first germination count.

In Londrina, factors had no significant effect on seed productivity. In Mauá da Serra, seed productivity in treatments with no application of trinexapac-ethyl fitted to an increasing linear functionn in response to higher $\mathrm{N}$ fertilization. On the other hand, treatments with application of the plant growth retardant fitted to a quadratic equation, peaking at $44.83 \mathrm{~kg} \cdot \mathrm{ha}^{-1}$ $\mathrm{N}$ (Figure 2). For all evaluated $\mathrm{N}$ levels, treatments with application of the plant growth retardant led to the highest values for such a trait. The use of trinexapac-ethyl led to an average increase of $51.22 \%$ in seed productivity when compared to treatments with no application of the product (Table 1).

A higher productivity in function of the application of trinexapac-ethyl can partly be due to a reduction in plant height and lodging and changes in leaf architecture, especially of the flag leaf, which becomes more upright (Penckowski and Fernandes, 2010), thus increasing the use of environmental resources, especially solar radiation (Zagonel and Fernandes, 2007). Such effects can change the partitioning of photoassimilates and improve their redirection to seed production (Kaspary et al., 2015). Souza et al. (2010) and Penckowski et al. (2009) reported that the use of plant growth retardants led to an increase in the productivity of winter cereals. Hawerroth et al. (2015) evaluated the effect of $\mathrm{N}$ fertilization, the application of trinexapac-ethyl, and growing environments on white oat crop and observed that productivity showed changeable responses to the application of the plant growth retardant depending on the growing environment.

Regardless of the application of the plant growth retardant, $\mathrm{N}$ topdressing led to an increase in seed productivity in Mauá da Serra. Kolchinski and Schuch (2003), who evaluated four graniferous white oat cultivars (CTC 5, UFRGS 15, UFRGS
19, and UPF 18) combined with four $\mathrm{N}$ levels $(0,24,48$, and $73 \mathrm{~kg} \cdot \mathrm{ha}^{-1}$ ), and by Prando et al. (2012a), who evaluated three wheat genotypes (cultivars 'BRS 208' and 'BRS Pardela', and the line 'IWT 04008') and four topdressing $\mathrm{N}$ levels $\left(0,40,80\right.$, and $\left.120 \mathrm{~kg}^{2} \mathrm{ha}^{-1}\right)$ also observed an increase in seed productivity in response to the increase of $\mathrm{N}$ levels in coverage. According to Soratto et al. (2007), N is capable of changing crop yield components and positively influencing seed productivity due to its multiple functions in plants, a fact that can have occurred with the cultivar 'IPR Afrodite' grown in Mauá da Serra.

The application of the plant growth retardant affected seed germination based on the percentage of normal seedlings

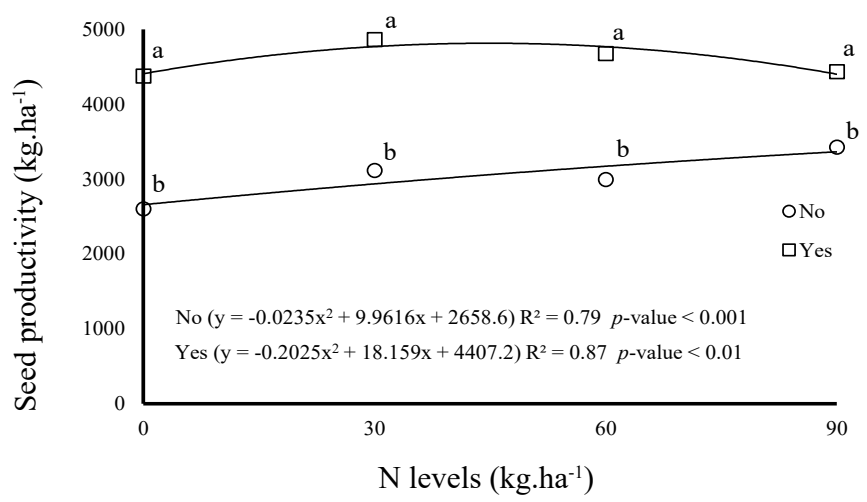

Figure 2. Seed productivity of the white oat cultivar 'IPR Afrodite' in Mauá da Serra-PR in function of the application of the plant growth retardant trinexapac-ethyl and topdressing $\mathrm{N}$ levels.

Table 1. Average values of seed productivity (PROD), germination $(\mathrm{G})$, first germination count (FGC), accelerated aging (AA), and electrical conductivity (EC) in the white oat cultivar 'IPR Afrodite' in function of the plant growth retardant trinexapac-ethyl.

\begin{tabular}{|c|c|c|c|c|}
\hline \multirow{2}{*}{$\begin{array}{l}\text { Plant growth } \\
\text { retardant }\end{array}$} & \multicolumn{4}{|c|}{ Londrina } \\
\hline & $\begin{array}{l}\mathrm{G} \\
(\%)\end{array}$ & \multicolumn{2}{|c|}{$\begin{array}{l}\text { AA } \\
(\%)\end{array}$} & $\begin{array}{c}\mathrm{EC} \\
\left(\mu \mathrm{S} . \mathrm{cm}^{-1} \cdot \mathrm{g}^{-1}\right)\end{array}$ \\
\hline No & $98 \mathrm{a}$ & \multicolumn{2}{|c|}{$93.25 \mathrm{a}$} & $127.37 \mathrm{~b}$ \\
\hline Yes & $97 \mathrm{~b}$ & \multicolumn{2}{|c|}{$77.37 \mathrm{~b}$} & $157.05 \mathrm{a}$ \\
\hline CV (\%) & 2.05 & \multicolumn{2}{|c|}{8.60} & 25.61 \\
\hline \multirow{2}{*}{$\begin{array}{l}\text { Plant growth } \\
\text { retardant }\end{array}$} & \multicolumn{4}{|c|}{ Mauá da Serra } \\
\hline & $\begin{array}{c}\text { PROD } \\
\left(\mathrm{kg} \cdot \mathrm{ha}^{-1}\right)\end{array}$ & $\begin{array}{c}G \\
(\%) \\
\end{array}$ & $\begin{array}{c}\text { FGC } \\
(\%)\end{array}$ & $\begin{array}{c}\text { EC } \\
\left(\mu \mathrm{S} . \mathrm{cm}^{-1} \cdot \mathrm{g}^{-1}\right)\end{array}$ \\
\hline No & $3032.86 \mathrm{~b}$ & $95 \mathrm{~b}$ & $85 \mathrm{~b}$ & $28.67 \mathrm{~b}$ \\
\hline Yes & $4586.51 \mathrm{a}$ & $98 \mathrm{a}$ & $91 \mathrm{a}$ & $49.03 \mathrm{a}$ \\
\hline C.V (\%) & 7.35 & 1.64 & 10.30 & 11.53 \\
\hline
\end{tabular}

*Means followed by the same letter in the column do not differ by the F-test $(\mathrm{P}<0.05)$. 
in Londrina and Mauá da Serra (Table 1). In Londrina, the application of trinexapac-ethyl led to a reduction of $1 \%$ in seed germination when compared to treatments with no application. Although the plant growth retardant have led to a lower germination, such a difference is small and, biologically, it does not affect seed performance in the growth and the initial development of seedlings in the field.

In Mauá da Serra, the use of the plant growth retardant led to an increase in seed germination (Table 1), as also observed by Kappes et al. (2012), who studied the effect of the application of three plant growth regulators (mepiquat chloride, trinexapacethyl, and paclobutrazol) at different levels $(0,75,150,225$, and $\left.300 \mathrm{~g} . \mathrm{ha}^{-1}\right)$ on crotalaria seed physiological quality and seedling growth and observed a positive influence of trinexapac-ethyl application. According to Nóbrega et al. (1999), this result can be due to a lower plant height in function of the application of the plant growth retardant, leading to the redirection of photoassimilates to reproductive structures, thus contributing to a higher germination potential.

In both environments, $\mathrm{N}$ topdressing had no effect on seed germination percentage. This result is partly due to soil conditions of both growing locations, since they present high fertility, and due to crop rotation with soybean, which probably left nutrients in the soil, especially $\mathrm{N}$, for oat crop. Then, even in the control group with application of only 30 and $20 \mathrm{~kg} \cdot \mathrm{ha}^{-1} \mathrm{~N}$ in Londrina and Mauá da Serra, respectively, and with no topdressing, seeds with high physiological quality were produced. Smiderle et al. (2011) studied different $\mathrm{N}$ levels and periods of application on the rice cultivar 'BRS Jaçanã' and observed the highest germination at $105 \mathrm{~kg} \mathrm{ha}^{-1}$ N. Carvalho and Nakagawa (2012) stated that an increase in germination percentage in function of $\mathrm{N}$ levels is probably due to such a nutrient is related to the formation of embryo and storage organs. Studies carried out with black oat (Nakagawa et al., 1994), white oat (Kolchinski and Schuch, 2004), wheat (Prando et al., 2012b; Brzezinski et al., 2014), sweet corn (Zucareli et al., 2012), and millet (Abrantes et al., 2010) also did not observe $\mathrm{N}$ effect on seed germination.

Among treatments with and with no application of the plant growth retardant, the values obtained for seed germination in both growing locations were above the standard established for white oat seed commercialization by the Ministry of Agriculture, Livestock, and Food Supply (Brasil, 2009), which requires at least $80 \%$ germination.

In Londrina, the plant growth retardant, $\mathrm{N}$ topdressing, and their interaction had no effect on first germination count. On the other hand, in Mauá da Serra, such a variable was increased at $6 \%$ by the use of the plant growth retardant when compared to treatments with no application (Table 1).
The implication of this result is that seeds from plants that were submitted to the application of the growth retardant in Mauá da Serra present a higher speed of germination, resulting in a faster and uniform seedling emergence, with better establishment of the initial plant stand, which increases the possibility of high productivities. Kappes et al. (2012) obtained similar results in crotalaria crop, in which the use of $225 \mathrm{~g}$ ha $^{-1}$ trinexapac-ethyl also led to an increase in the percentage of normal seedlings at the first germination count. In turn, Souza et al. (2010) evaluated levels and periods of application of three plant growth regulators on wheat and did not observe significant effect of products on the percentage of normal seedlings at the first germination count.

In Mauá da Serra, the first germination count fitted to a quadratic function in response to higher $\mathrm{N}$ levels, with minimum values at 38.74 kg.ha ${ }^{-1} \mathrm{~N}$ (Figure 3). These results show that the higher germination rates are observed in the higher $\mathrm{N}$ rates, since probably the increase of the nutrient supply to the plant caused a greater development of the leaf area and, therefore, allowed a better accumulation of reserves in the seed, making its germination more vigorous. In this way, lower doses of $\mathrm{N}$ probably caused less development of the leaf area, which resulted in a lower contribution of photoassimilates to the seeds, which resulted in the lower germination speed. These facts may explain the quadratic fit for this characteristic.

In Londrina, the length of white oat seedlings was significantly influenced by the interaction between the factors plant growth retardant and topdressing $\mathrm{N}$ levels. For such a trait, treatments with no application of trinexapac-ethyl fitted to a decreasing linear function in response to higher $\mathrm{N}$ fertilization (Figure 4a). In turn, treatments with application of the plant growth retardant fitted to a quadratic equation, peaking at 26.97

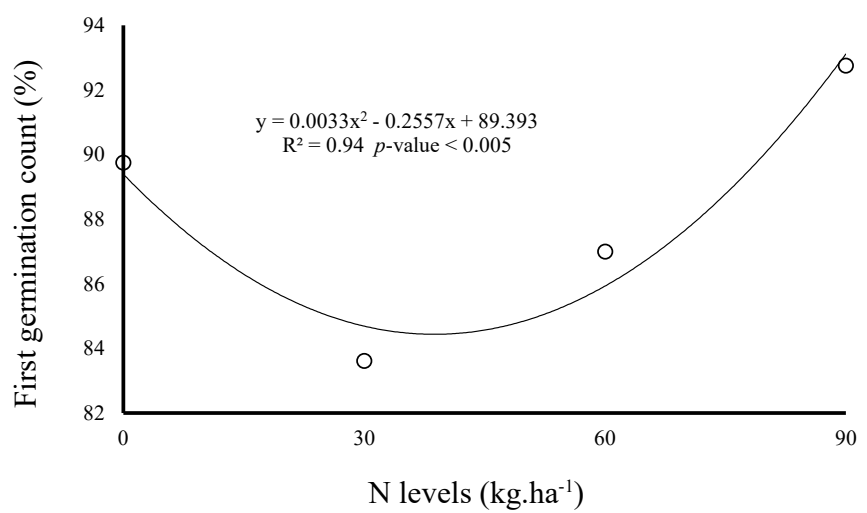

Figure 3. First germination count in white oat seeds of the cultivar 'IPR Afrodite' in Mauá da Serra-PR in function of topdressing $\mathrm{N}$ levels. 
kg.ha- ${ }^{-1}$ N. Except at $30 \mathrm{~kg} \cdot \mathrm{ha}^{-1} \mathrm{~N}$, treatments with no application of the plant growth retardant led to the highest values of such a variable for all evaluated $\mathrm{N}$ levels (Figure 4a).

In Mauá da Serra, seedling length was also influenced by the interaction between plant growth retardant and topdressing $\mathrm{N}$ levels. At 0,30 , and $60 \mathrm{~kg} \cdot \mathrm{ha}^{-1} \mathrm{~N}$, the highest values were observed for treatments with application of trinexapac-ethyl, while no difference among treatments was detected at 90 kg.ha ${ }^{-1} N$ (Figure $4 b$ ). Seedling length under application of the plant growth retardant fitted to a decreasing linear equation in response to $\mathrm{N}$ topdressing. A quadratic model led to the best fit of seedling length results when trinexapac-ethyl was not applied. Such an equation indicates that the lowest value $(20.49 \mathrm{~cm})$ was obtained at $40.68 \mathrm{~kg} \cdot \mathrm{ha}^{-1} \mathrm{~N}$.

In Londrina, seedling dry matter was influenced by the interaction between the factors plant growth retardant and $\mathrm{N}$ levels. Treatments with no application of trinexapac-ethyl fitted to a decreasing linear equation in response to higher $\mathrm{N}$ fertilization (Figure 5a). On the other hand, treatments with application of the plant growth retardant fitted to a quadratic function, peaking $(9.2 \mathrm{mg})$ at $35.5 \mathrm{~kg} \cdot \mathrm{ha}^{-1} \mathrm{~N}$. Except at 30 $\mathrm{kg} \cdot \mathrm{ha}^{-1} \mathrm{~N}$, treatments with no application of the plant growth retardant led to the highest values of such a variable for all evaluated $\mathrm{N}$ levels (Figure 5a).

In Mauá da Serra, seedling dry matter was significantly influenced by the interaction between the factors plant growth retardant and topdressing $\mathrm{N}$ levels. Treatments with and with no application of trinexapac-ethyl fitted to quadratic functions in response to higher $\mathrm{N}$ fertilization, with maximum and minimum values obtained at 29.25 and $44.28 \mathrm{~kg} \cdot \mathrm{ha}^{-1}$ $\mathrm{N}$, respectively. For evaluated $\mathrm{N}$ levels, treatments with application of the plant growth retardant led to the highest values of such a trait (Figure 5b).

Regarding accelerated aging, a lower seed germination was observed under application of trinexapac-ethyl in the experiment carried out in Londrina (Table 1). Kappes et al. (2012) and Souza et al. (2010) evaluated three plant growth regulators (mepiquat chloride, trinexapac-ethyl, and paclobutrazol) on crotalaria and wheat crops, respectively, and did not observe significant effect of products on germination after accelerated aging. As to topdressing $\mathrm{N}$ levels, accelerated aging fitted to a quadratic function, with the lowest value $(80.69 \%)$ at 43.98 kg.ha- ${ }^{-1} \mathrm{~N}$ (Figure 6a). Conversely, other studies evaluating the effect of $\mathrm{N}$ topdressing on the germination of seeds submitted to the accelerated aging test did not observe responses of such a management technique on this trait, e.g. Kolchinski and Schuch $(2003,2004)$ in white oat, Nakagawa et al. (1994) in black oat, Egewarth et al. (2015) in canola, and Zucareli et al. (2012) in sweet corn.
A significant interaction between plant growth retardant and topdressing $\mathrm{N}$ levels was detected for accelerated aging in the experiment carried out in Mauá da Serra. Treatments with and with no application of trinexapac-ethyl fitted to quadratic functions in response to higher $\mathrm{N}$ levels (Figure $6 \mathrm{~b}$ ). The highest seed germination values in the accelerated aging test were $89 \%$ and $100 \%$, at 28.90 and $29 \mathrm{~kg} \cdot \mathrm{ha}^{-1} \mathrm{~N}$ in treatments with and with no application of the plant growth retardant, respectively. At $60 \mathrm{~kg} \cdot \mathrm{ha}^{-1} \mathrm{~N}$, the highest values were detected in the absence of trinexapac-ethyl, while $90 \mathrm{~kg} \cdot \mathrm{ha}^{-1} \mathrm{~N}$ led to the highest values under trinexapac-ethyl application. In other levels, no significant differences were observed among treatments for accelerated aging.

In order to explain these results, we can cite some works conducted with wheat and white oat crops (Prando et al., 2012a; Kaspary et al., 2015), which revealed that nitrogen fertilization and the application of the growth retardant increases the number of spikes. $\mathrm{m}^{-2}$. In the present study, the use of these treatments on white oat culture may have increased the number of panicles. $\mathrm{m}^{-2}$, causing intraspecific competition,
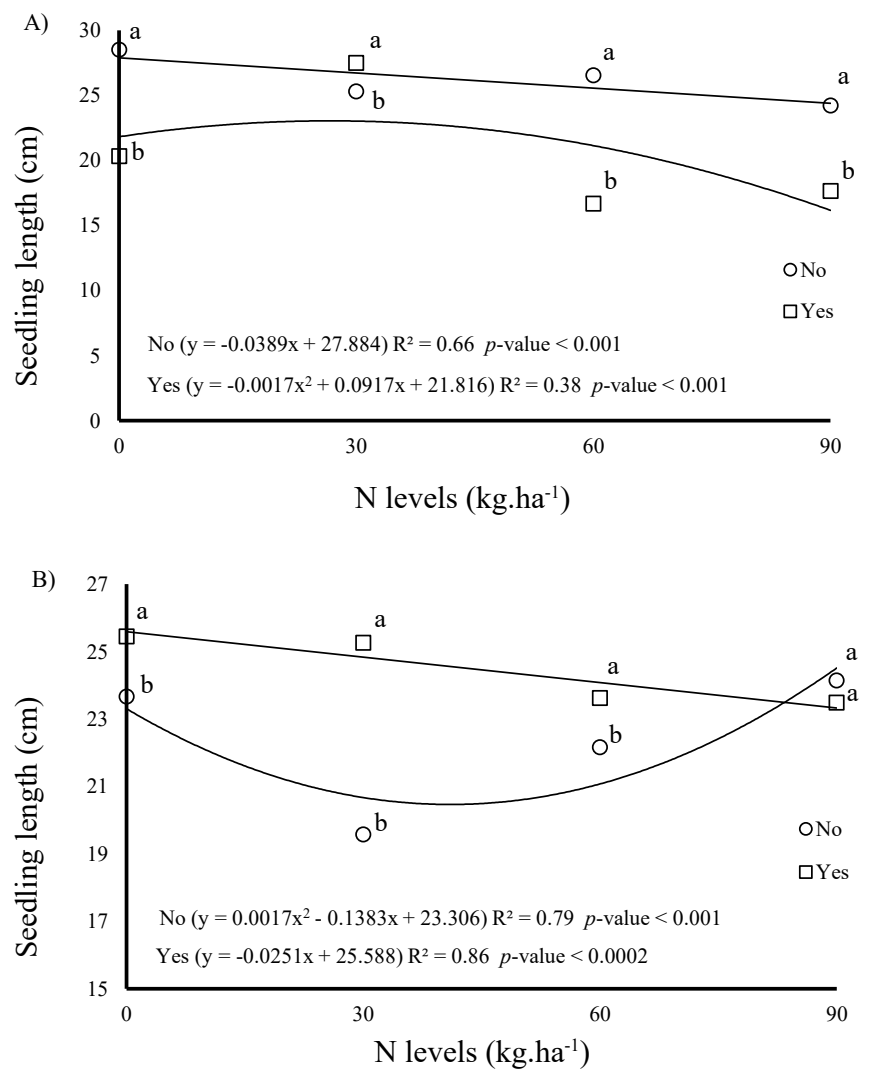

Figure 4. Seedling length of the white oat cultivar 'IPR Afrodite' in Londrina-PR (A) and Mauá da Serra-PR (B) in function of the application of the plant growth retardant trinexapac-ethyl and topdressing $\mathrm{N}$ levels. 

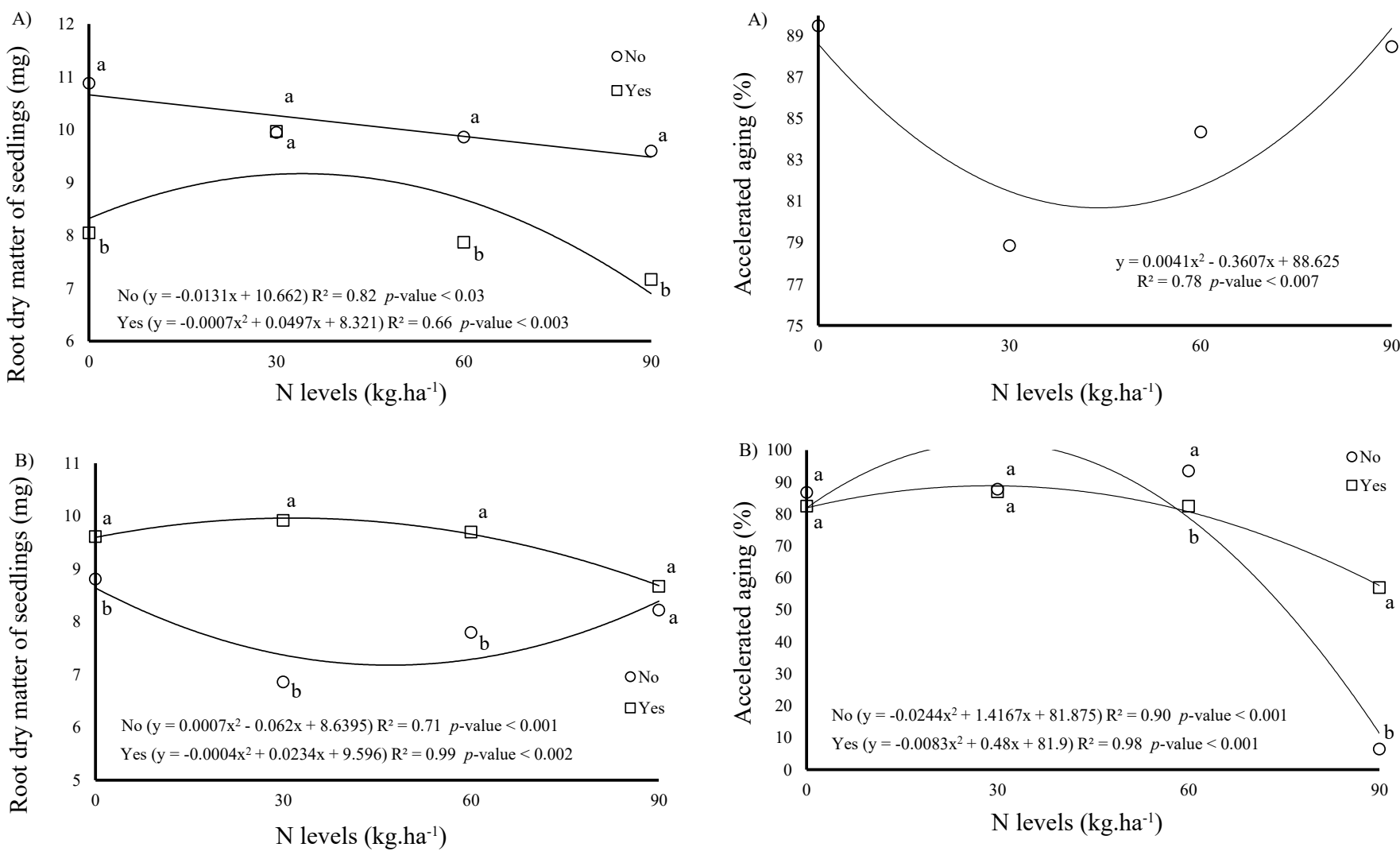

Figure 5. Root dry matter of seedlings of the white oat cultivar 'IPR Afrodite' in Londrina-PR (A) and Mauá da Serra-PR (B) in function of the application of the plant growth retardant trinexapac-ethyl and topdressing $\mathrm{N}$ levels.

a fact that may have impaired the adequate filling of the seeds and negatively influenced the physiological potential of seeds (accelerated aging) in the higher doses of $\mathrm{N}$.

As shown in Table 1, the results of electrical conductivity indicate that the application of trinexapac-ethyl led to a negative effect on the vigor of seeds produced in Londrina and Mauá da Serra. According to Motta et al. (2002) and Gomes et al. (2012), growing locations can influence seed physiological quality (including electrical conductivity) as they provide better or worse soil and climatic conditions during seed formation, growth and development. Treatments with application of the plant growth retardant resulted in an increase of $39.81 \mu \mathrm{S} . \mathrm{cm}^{-1} . \mathrm{g}^{-1}$ and $32.13 \mu \mathrm{S} . \mathrm{cm}^{-1} . \mathrm{g}^{-1}$ in the electrical conductivity of seeds produced in Londrina and Mauá da Serra, respectively, when compared to treatments with no application. Higher electrical conductivity values are due to a higher release of exudates in the imbibition solution because of the impairment of membrane integrity, thus indicating low quality seeds (Vieira and Krzyzanowski, 1999).

Figure 6. Accelerated aging in white oat seeds of the cultivar 'IPR Afrodite' in Londrina-PR (A) in response to topdressing $\mathrm{N}$ levels and in Mauá da Serra-PR (B) in function of the application of the plant growth retardant trinexapac-ethyl and topdressing $\mathrm{N}$ levels.

In the experiment carried out in Londrina, no significant effect of the plant growth retardant, topdressing $\mathrm{N}$ levels, and their interaction was detected on seedling emergence in sand. On the other hand, in Mauá da Serra, a significant interaction between the two factors was observed for such a trait. In Figure 7, treatments with no application of the plant growth retardant did not lead to responses of seedling emergence in sand to an increase in $\mathrm{N}$ topdressing. However, such a trait was positively influenced under application of trinexapac-ethyl, with a linear increase in the percentage of emerged seedlings as higher $\mathrm{N}$ levels. No significant differences were detected among topdressing $\mathrm{N}$ levels regardless of the application of trinexapac-ethyl. The application of the growth retardant, for its probable action on the foliar architecture, may have promoted the formation of more compact plants with erect leaves, which could have resulted in a better utilization of the solar radiation by the crop and favored the redistribution of photoassimilates in a more efficient way for the seeds, causing the formation of seeds with greater capacity of emergency in the field. 


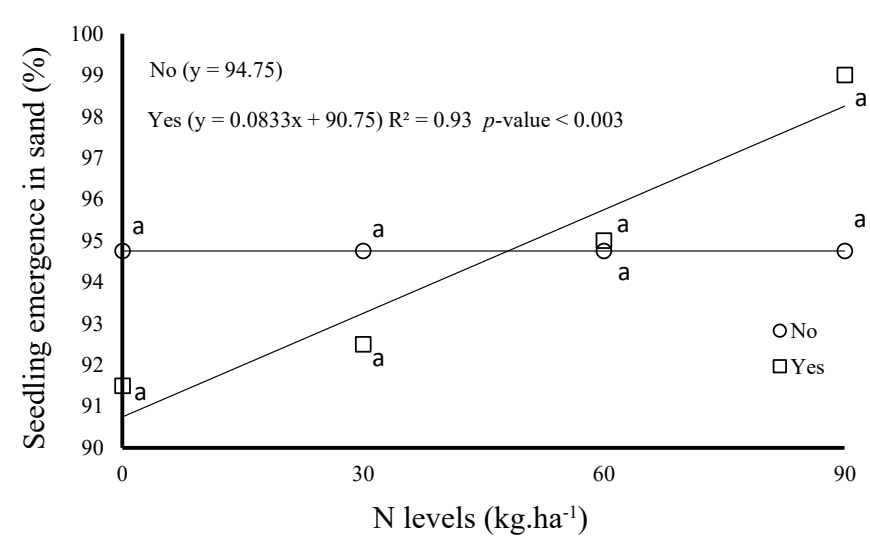

Figure 7. Emergence in sand of white oat seedlings of the cultivar 'IPR Afrodite' in Mauá da Serra-PR in function of the application of the plant growth retardant trinexapac-ethyl and topdressing $\mathrm{N}$ levels.

\section{Conclusions}

The application of the plant growth retardant and $\mathrm{N}$ topdressing leads to an increase in seed productivity in the growing environment located in Mauá da Serra.

$\mathrm{N}$ topdressing reduces seed quality. However, this effect can be minimized, not observed or overlapped by the positive effect of the plant growth retardant. This effect depends on the characteristics of the growing environment and was not observed in Londrina.

\section{References}

ABRANTES, F.L.; KULCZYNSKI, S.M.; SORATTO, S.P.; BARBOSA, M.M.M. Nitrogênio em cobertura e qualidade fisiológica e sanitária de sementes de painço (Panicum miliaceum L.). Revista Brasileira de Sementes, v.32, n.3, p.106-115, 2010. http://www.scielo.br/pdf/rbs/v32n3/v32n3a12.pdf

BRASIL. Ministério da Agricultura, Pecuária e Abastecimento. Regras para análise de sementes. Ministério da Agricultura, Pecuária e Abastecimento. Secretaria de Defesa Agropecuária. Brasília, DF: MAPA/ACS, 2009. 395p. http://www.agricultura.gov.br/assuntos/ insumos-agropecuarios/arquivos-publicacoes-insumos/2946 regras_analise_sementes.pdf

BRZEZINSKI, C.R.; ZUCARELI, C.; HENNING, F.A.; ABATI, J.; PRANDO, A.M.; HENNING, A.A. Nitrogênio e inoculação de Azospirillum na qualidade fisiológica e sanitária de sementes de trigo. Revista de Ciências Agrárias, v.57, n.3, p.257-265, 2014. http://doi.editoracubo.com.br/10.4322/rca.ao1391

CARVALHO, N.M.; NAKAGAWA, J. Sementes: ciência, tecnologia e produção. 5.ed. Jaboticabal: FUNEP, 2012. 590p.
CBPA - COMISSÃO BRASILEIRA DE PESQUISA DE AVEIA. Indicações técnicas para cultura da aveia: XXXIV Reunião da Comissão Brasileira de Pesquisa de Aveia: Fundação ABC, 2014. 136p.

EGEWARTH, J.F.; GUIMARÃES, V.F.; PINTO JUNIOR, A.S.; EGEWARTH, V.A.; PIANO, J.T.; WACHHOLZ, L. Qualidade fisiológica de sementes de canola em função de diferentes fontes e parcelamentos da fertilização nitrogenada. Journal of Agronomic Sciences, v.4, n.2, p.213223, 2015. http://www.dca.uem.br/V4N2/19.pdf

ESPINDULA, M.C.; ROCHA, V.S.; SOUZA, M.A.; GROSSI, J.A.S.; SOUZA, L.T. Efeitos de reguladores de crescimento na elongação do colmo de trigo. Acta Scientiarum Agronomy, v.32, n.1, p.109-116, 2010. http://www.scielo.br/pdf/asagr/v32n1/v32n1a16

GOMES, G.D.R.; BENIN, G.; ROSINHA, R.C.; GALVAN, D.; PAGLIOSA, E.S.; PINNOW, C.; SILVA, C.L.; BECHE, E. Produção e qualidade fisiológica de sementes de soja em diferentes ambientes de cultivo. Semina Ciências Agrárias, v.33, supl.1, p.2593-2604, 2012. http://www.uel.br/revistas/uel/index.php/semagrarias/article/view/8142

HAWERROTH, M.C.; SILVA, J.A.G.; SOUZA, C.A.; OLIVEIRA, A.C.; LUCHE, H.S.; ZIMMER, C.M.; HAWERROTH, F.J.; SCHIAVO, J.; SPONCHIADO, J.C. Redução do acamamento em aveia branca com uso do regulador de crescimento etil-trinexapac. Pesquisa Agropecuária Brasileira, v.50, n.2, p.115-125, 2015. https://seer.sct.embrapa.br/index.php/pab/article/view/19362

KAPPES, C.; ARF, O.; SÁ, M.E.; FERREIRA, J.P.; PORTUGAL, J.R.; ALCALDE, A.M.; VILELA, R.G. Reguladores de crescimento e seus efeitos sobre a qualidade fisiológica de sementes e crescimento de plântulas de crotalaria. Bioscience Journal, v.28, n.2, p.180-190, 2012. http://www.seer.ufu.br/index.php/biosciencejournal/article/view/11639

KASPARY, T.E.; LAMEGO, F.P.; BELLÉ, C.; KULCZYNSKI, S.M.; PITTOL, D. Regulador de crescimento na produtividade e qualidade de sementes de aveia-branca. Planta Daninha, v.33, n.4, p.739-750, 2015. http://www.scielo.br/pdf/pd/v33n4/0100-8358pd-33-04-00739.pdf

KOLCHINSKI, E.M.; SCHUCH, L.O.B. Atributos de desempenho industrial e qualidade de sementes em aveia branca em função da disponibilização da adubação nitrogenada. Ciência Rural, v.33, n.3, p.582-589, 2003. http://www.scielo.br/pdf/cr/v33n3/a31v33n3.pdf

KOLCHINSKI, E.M.; SCHUCH, L.O.B. Relações entre a adubação nitrogenada e a qualidade de grãos e de sementes em aveia branca. Ciência Rural, v.34, n.2, p.379-383, 2004. http://www.scielo.br/pdf/ $\mathrm{cr} / \mathrm{v} 34 \mathrm{n} 2 / \mathrm{a} 07 \mathrm{v} 34 \mathrm{n} 2 . \mathrm{pdf}$

MAGUIRE, J.D. Speed of germination-aid in selection and evaluation for seedling emergence and vigor. Crop Science, v.2, n.1, p.176-177, 1962.

MARCOS-FILHO, J. Testes de vigor: importância e utilização. In: KRZYZANOWSKI, F.C.; VIEIRA, R.D., FRANÇA-NETO, J.B. (Ed.). Vigor de sementes: conceitos e testes. Londrina: ABRATES, 1999. p.1-21.

MOTTA, I.S.; BRACCINI, A.L.; SCAPIM, C.A.; INOUE, M.H.; ÁVILA, M.R.; BRACCINI, M.C.L. Época de semeadura em cinco cultivares de soja. II. Efeito na qualidade fisiológica das sementes. Acta Scientiarum. Agronomy, v.24, n.5, p.1281-1286, 2002. http:// periodicos.uem.br/ojs/index.php/ActaSciAgron/article/view/2291 
NAKAGAWA, J. Testes de vigor baseados na avaliação das plântulas. In: KRZYZANOWSKI, F.C.; VIEIRA, R. D.; FRANÇANETO, J. B. (Ed.). Vigor de sementes: conceitos e testes. Londrina: ABRATES, 1999. p.2.1-2.21.

NAKAGAWA, J.; CAVARIANI, C.; AMARAL, W.A.N.; MACHADO, J.R. Produção e qualidade de sementes de aveia preta (Avena strigosa Schreb.) em função da adubação nitrogenada. Revista Brasileira de Sementes v.16, n.1, p.95-101, 1994. http:// www.bibliotekevirtual.org/revistas/RBS/v16n01/v16n01a20.pdf

NÓBREGA, L.B.; VIEIRA, D.J.; BELTRÃO, N.E.M.; AZEVEDO, D.M.P. Hormônios e reguladores do crescimento e do desenvolvimento. In: BELTRÃO, N. E. M. (Org.). O agronegócio do algodão no Brasil. Brasília: Embrapa Comunicação para Transferência de Tecnologia, 1999. p.587-602.

OLIVEIRA, S.; TAVARES, L.C.; LEMES, E.S.; BRUNES, A.P.; DIAS, I.L.; MENEGHELLO, G.E. Tratamento de sementes de Avena sativa L. com zinco: qualidade fisiológica e desempenho inicial de plantas. Semina: Ciências Agrárias, v.35, n.3, p.11311142, 2014. http://www.uel.br/revistas/uel/index.php/semagrarias/ article/viewFile/13599/14517

PAGLIOSA, E.E.; BENIN, G.; BIEZUS, E.; BECHE, E.; SILVA, C.L.; MARCHESE, J.A.; MARTIN, T.N. Trinexapac-ethyl e adubação nitrogenada na cultura do trigo. Planta Daninha, v.31, n.3, p.623-630, 2013. http://www.scielo.br/pdf/pd/v31n3/14.pdf

PENCKOWSKI, L.H.; FERNANDES, E.C. Utilizando regulador de crescimento na cultura de trigo: aspectos importantes para garantir bons resultados. 3.ed. Castro: Fundação ABC, 2010. 68p.

PENCKOWSKI, L.H.; ZAGONEL, J.; FERNANDES, E.C. Nitrogênio e redutor de crescimento em trigo de alta produtividade. Acta Scientiarum Agronomy, v.31, n.3, p.473-479, 2009. http://www. scielo.br/pdf/asagr/v31n3/a16v31n3.pdf

PRANDO, A.M.; ZUCARELI, C.; FRONZA, V.; BASSOI, M.C.; OLIVEIRA, F.A. Formas de ureia e doses de nitrogênio em cobertura no desempenho agronômico de genótipos de trigo. Semina: Ciências Agrárias, v.33, n.2, p.621-632, 2012a. http://www.uel.br/revistas/ uel/index.php/semagrarias/article/viewFile/8637/10447

PRANDO, A.M.; ZUCARELI, C.; FRONZA, V.; OLIVEIRA, E.A.P.; PANOFF, B. Formas de ureia e doses de nitrogênio em cobertura na qualidade fisiológica de sementes de trigo. Revista Brasileira de Sementes, v.34, n.2, p.272-279, 2012b. http://www. scielo.br/pdf/rbs/v34n2/12.pdf
RADEMACHER, W. Plant growth regulators: backgrounds and uses in plant prodution. Journal of Plant Growth Regulation, v.34, n.4, p.845-872, 2015. https://link.springer.com/article/10.1007/s00344$015-9541-6$

SÁ, M.E. Importância da adubação nitrogenada na qualidade de sementes. In: SÁ, M.E.; BUZZETTI, S. Importância da adubação na qualidade dos produtos agrícolas. São Paulo: Icone, 1994. p. 65-98.

SAWAN, Z.M.; FAHMY, A.H.; YOUSEF, S.E. Direct and residual effects of nitrogen fertilization, foliar application of potassium and plant growth retardant on Egyptian cotton growth, seed yield, seed viability and seedling vigor. Acta Ecologica Sinica, v.29, p.116-123, 2009. http://www.sciencedirect.com/science/article/pii/ S1872203209000183

SMIDERLE, O.J.; CHANG, M.T.; FERREIRA, G.B.; CORDEIRA, A.C.C. Qualidade de sementes de arroz BRS Jaçanã em função de aplicações de nitrogênio. Ciências Agrárias e Ambientais, v.9, n.1, p.79-86, 2011. https://periodicos.pucpr.br/index.php/cienciaanimal/ article/view/11102

SORATTO, R.P.; CARDOSO, S.M.; SILVA, A.H.; COSTA, T.A.M.; PEREIRA, M.; CARVALHO, L.A. Doses e épocas de aplicação de nitrogênio em cobertura na cultura do painço (Panicum miliaceum L.). Ciência e Agrotecnologia, v.31, n.6, p.1661-1667, 2007. http:// www.scielo.br/pdf/cagro/v31n6/a09v31n6.pdf

SOUZA, L.T.; ESPÍNDULA, M.C.; ROCHA, V.S.; DIAS, D.C.F.S.; SOUZA, M.A. Growth retardants in wheat and its effect in physiological quality of seeds. Ciência Rural, v.40, n.6, p.14311434, 2010. http://www.scielo.br/pdf/cr/v40n6/a601cr2081.pdf

VIEIRA, R.D.; KRZYZANOWSKI, F.C. Teste de condutividade elétrica. In: KRZYZANOWSKI, F. C.; VIEIRA, R. D.; FRANÇANETO, J. B. (Ed.). Vigor de sementes: conceitos e testes. Londrina: ABRATES, 1999. p.1-26.

ZAGONEL, J.; FERNANDES, E.C. Doses e épocas de aplicação do regulador de crescimento afetando cultivares de trigo em duas doses de nitrogênio. Planta Daninha, v.25, n.2, p.331-339, 2007. http:// www.scielo.br/pdf/pd/v25n2/a13v25n2.pdf

ZUCARELI, C.; PANOFF, B.; PORTUGAL, G.; FONSECA, I.C.B. Doses e épocas de aplicação de nitrogênio em cobertura na qualidade fisiológica de sementes de milho doce. Revista Brasileira de Sementes, v.34, n.3, p.480-487, 2012. http://www.scielo.br/pdf/ $\mathrm{rbs} / \mathrm{v} 34 \mathrm{n} 3 / 16 . \mathrm{pdf}$ 